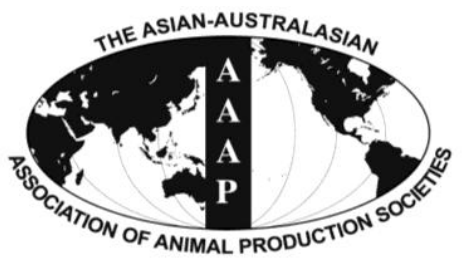

Asian-Aust. J. Anim. Sci.

Vol. 25, No. 6 : 800 - 805

June 2012

www.ajas.info

http://dx.doi.org/10.5713/ajas.2011.11409

\title{
Mutation of Cellulose Synthase Gene Improves the Nutritive Value of Rice Straw
}

\author{
Yanjing Su, Guoqi Zhao*, Zhenwu Wei, Changjie Yan $^{1}$ and Sujiao Liu \\ College of Animal Science and Technology, Yangzhou University, Yangzhou 225009, China
}

\begin{abstract}
Rice straw is an important roughage resource for ruminants in many rice-producing countries. In this study, a rice brittle mutant (BM, mutation in OsCesA4, encoding cellulose synthase) and its wild type (WT) were employed to investigate the effects of a cellulose synthase gene mutation on rice straw morphological fractions, chemical composition, stem histological structure and in situ digestibility. The morphological fractions investigation showed that BM had a higher leaf sheath proportion $(43.70 \%$ vs $38.21 \%$, $\mathrm{p}<0.01)$ and a lower leaf blade proportion $(25.21 \%$ vs $32.14 \%, \mathrm{p}<0.01)$ than WT. Chemical composition analysis showed that BM rice straw was significantly $(\mathrm{p}<0.01)$ higher in CP (crude protein), hemicellulose and acid insoluble ash (AIA) contents, but lower in dry matter (DM), acid detergent fiber (ADFom) and cellulose contents when compared to WT. No significant difference ( $p>0.05$ ) was detected in neutral detergent fiber (NDFom) and ADL contents for both strains. Histological structure observation indicated that BM stems had fewer sclerenchyma cells and a thinner sclerenchyma cell wall than WT. The results of in situ digestion showed that BM had higher DM, NDFom, cellulose and hemicellulose disappearance at 24 or $48 \mathrm{~h}$ of incubation $(\mathrm{p}<0.05)$. The effective digestibility of BM rice straw DM and NDFom was greater than that of WT (31.4\% vs $26.7 \%$ for DM, $29.1 \%$ vs $24.3 \%$ for NDFom, p<0.05), but the rate of digestion of the slowly digested fraction of BM rice straw DM and NDF was decreased. These results indicated that the mutation in the cellulose synthase gene could improve the nutritive value of rice straw for ruminants. (Key Words: Cellulose Synthase, Rice Straw, Histological Structure, In situ Digestibility)
\end{abstract}

\section{INTRODUCTION}

Rice straw is an important roughage resource for ruminants in many rice-producing countries. In China, the annual yield of rice straw is about 188 million tons (Guo et al., 2002). However, the utilization efficiency of rice straw is limited due to its low protein and energy value, high silica and consequently low digestibility. In many areas of China, rice straw is often burned in the field by farmers during harvest time, which occasionally induced serious environmental pollution. Therefore, in order to improve the utilization efficiency, many physical, chemical or biological pretreatments have been employed to improve rice straw nutritive quality, such as ammonification (Liu et al., 2002; Selim et al., 2004), urea treatment (Rahal et al., 1997; Vadiveloo and Fadel, 2009), steam spray (Liu and Ørskov,

\footnotetext{
* Corresponding Author: Guoqi Zhao. Tel: +86-514-8799-7195, Fax: +86-514-8735-0440, E-mail: jszhaoguoqi@ sohu.com ${ }^{1}$ Key Laboratory of Plant Functional Genomics, Ministry of Education/Jiangsu Key Laboratory of Crop Genetics and Physiology, Yangzhou University, Yangzhou 225009, China. Submitted Nov. 7, 2011; Accepted Jan. 11, 2012; Revised Feb. 3, 2012
}

2000; Weimer et al., 2003) and white rot fungi fermentation (Karunanandaa et al., 1995). Although these pretreatments showed some benefits for fermentation and animal production, additional costs and labor were required.

Previous studies have revealed that there was considerable genetic variation among varieties relative to the nutritive value of rice straw (Abou-El-Enin et al., 1999). A hybrid rice crossed with two low or high straw nutritive quality parents yielded higher dry matter digestiability (Singh and Singh, 1995; Sohane and Singh, 2000), which indicated that genetic improvement was an alternative approach to increase the nutritive value of rice straw. However, in most rice-producing countries the feeding value of rice straw was not considered in rice breeding programs. Mutagenesis is an important method for crop breeding, but few studies focused on the effect of gene mutagenesis on the nutritive value of rice straw.

A brittle mutant (BM) was obtained by means of ${ }^{60} \mathrm{Co}-\gamma$ radiation of a japonica rice variety Zhonghua-11 (Wild type, WT). This mutant displayed normal phenotype similar to its wild type except for the fragility of its whole plant body. The gene fine mapping and sequence analysis have revealed 
that this mutational phenotype was caused by the loss-offunction mutation in OsCesA4, which encoded cellulose synthase catalytic subunit (CesA) (Yan et al., 2007).

Many physical and chemical factors, including particle size, cell wall structure, cell wall components and so on, could affect forage intake and digestibility in ruminants (Jung and Allen, 1995). Therefore, these mutative traits of $\mathrm{BM}$ rice straw may be favorable for its efficient utilization by ruminants. Hence, the botanical fractions, chemical compositions, stem histological structure and dry matter digestibility were investigated in both BM and WT in order to estimate whether a cellulose synthase gene mutation could improve the nutritive value of rice straw.

\section{MATERIALS AND METHODS}

\section{The plant materials}

BM and WT were sown on the same day at the experimental farm of Yangzhou University in the natural growing season from June to September. BM exhibited the fragile culm and leaf (Figure 1). Apart from the brittle phenotype, there were no differences between BM and WT in terms of other agronomic characters, including plant height, heading date, tilling ability and seed set. At the yellow maturity stage, which corresponded to 122 days of growth after sowing, both strains were hand-harvested $5 \mathrm{~cm}$ above the ground, subsequently the grains were removed. The two strains were collected in triplicate from three replicate plots.

\section{Morphological proportion}

During harvest stage, five plant samples at each experimental plot were collected, then these straws were divided into stem, leaf blade and leaf sheath fractions, respectively. Leaves were removed from stem internodes, then leaf blade and leaf sheath were separated. Nodes and internodes were pooled to constitute the stem fraction. All fractions were dried at $65^{\circ} \mathrm{C}$ for $72 \mathrm{~h}$. The morphological proportion was estimated by weight of each fraction (on dry matter basis).

\section{Chemical composition analysis}

$\mathrm{BM}$ and WT rice straw were ground to pass $1 \mathrm{~mm}$ sieve

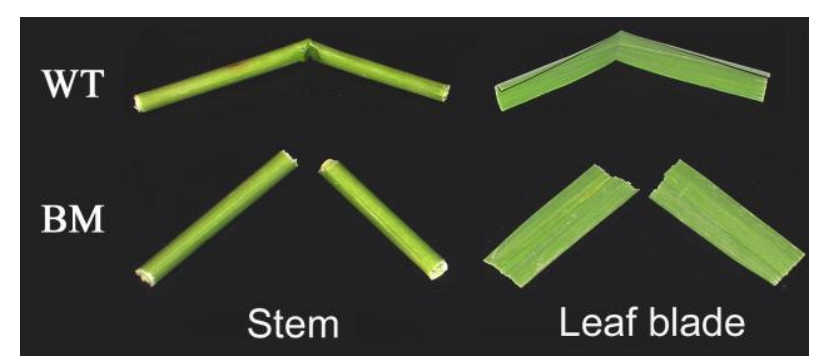

Figure 1. The phenotype of brittle mutant (BM) and its wild type (WT). for subsequent chemical analysis. Dry matter (DM), organic matter (OM) and crude protein (CP) were assayed according to AOAC (1999). Cellulose, hemicellulose, acid detergent lignin (ADL), acid insoluble ash (AIA), neutral detergent fiber (NDFom) and acid detergent fiber (ADFom) were measured following the procedures of Van Soest et al. (1991). NDFom and ADFom were calculated by subtracting the residual ash. Sulfite and heat stable amylase were not included in the procedure, and lignin content was determined using the sulfuric acid method. Hemicellulose was measured by subtracting ADFom from NDFom.

\section{In situ digestibility}

Three Holstein dairy cows with permanent rumen cannula fed alfalfa hay and corn silage based total mixed ration were used for the in situ digestion study. Nylon bags $(7 \times 14 \mathrm{~cm}$; pore size, $45 \mu \mathrm{m})$ containing approximately $3.0 \mathrm{~g}$ ground rice straw were placed into the rumen immediately before feeding at 08:00 am. Bags were removed from the rumen after $0,6,12,24,48$ and $72 \mathrm{~h}$ incubation for the determination of DM and rice straw components disappearance. These results were fitted to the exponential equation $\mathrm{P}=\mathrm{a}+\mathrm{b}\left(1-\mathrm{e}^{-\mathrm{ct}}\right)$, where $\mathrm{P}$ represents the disappearance rate at time $t$, whereas $a, b$ and $c$ are constants. a means The readily digested fraction represented by a, the slowly digested fraction represented by $b$, the rate of digestion of the slowly digested fraction represented by $c$, and the potentially digestible fraction represented by $a+b$ (Ørskov and McDonald, 1979). Effective digestibility (ED) was calculated by the equation $\mathrm{ED}=\mathrm{a}+(\mathrm{bc} /(\mathrm{c}+\mathrm{k}))$, where $\mathrm{k}$ represented passage rate (McDonald, 1981). In this study, the hypothetical $\mathrm{k}$ value was 0.025 . If the a value was negative, as noted by Wilman et al. (1996), it indicated a lag time before rapid degradation began, the length of the lag time was estimated as $(1 / \mathrm{c}) \ln [\mathrm{b} /(\mathrm{a}+\mathrm{b})]$ (McDonald, 1981).

\section{SEM and TEM investigation}

$\mathrm{BM}$ and WT stem samples (approximately $2 \mathrm{~mm} \times 5$ $\mathrm{mm}$ ) for scanning electron microscope (SEM) and transmission electron microscope (TEM) observation were taken from the second internode below the panicle. These samples were excised with a razor and immediately stored in $2.5 \%$ glutaraldehyde for approximately one month before post-fixation. After several rinses, the material was dehydrated in an ethanol series, critical point dried in $\mathrm{CO}_{2}$, spurted with gold and examined with SEM (Philips XL-30E ESEM, Holland).

Samples for TEM were rinsed, dehydrated as above and embedded in low viscosity resin. Thin sections (60 to 100 $\mathrm{nm}$ ) were cut with a diamond knife, collected on copper grids and stained with $1 \%$ aqueous uranylacetate for $15 \mathrm{~min}$ followed by 15 min in Reynold's lead citrate. The sections were examined with TEM (Phillips Tecnai 12, Holland). 


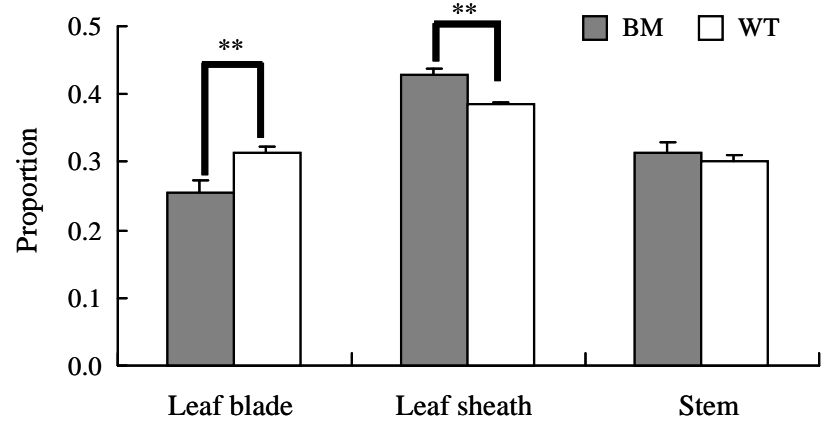

Figure 2. Morphological fraction proportions of brittle mutant $(\mathrm{BM})$ and its wild type (WT) rice straw (* means $\mathrm{p}<0.05, * *$ means $\mathrm{p}<0.01)$.

\section{Statistical analysis}

Statistical analysis was performed using statistical program for the social sciences (SPSS) software for Windows (version 15.0). The difference in DM, chemical compositions, in situ DM digestibility and digestion constants between BM and WT were identified by independent-sample $t$-test. The constant $a, b$ and $c$ were evaluated by nonlinear regression model.

\section{RESULTS}

\section{Morphological proportion}

Morphological fractions of BM and WT rice straw are shown in Figure 2. The stem proportion of both strains was similar, accounting for $30 \%$ approximately, while the leaf blade and sheath proportions were different between two strains. The leaf sheath proportion of BM, representing about $43 \%$, was significantly higher $(\mathrm{p}<0.01)$ than that of WT. On contrast, the leaf blade proportion of BM was significantly lower $(\mathrm{p}<0.01)$ than that of WT.

\section{Comparison of chemical compositions}

Gene mutation greatly altered BM rice straw chemical composition. Compared to WT, the hemicellulose, AIA and $\mathrm{CP}$ contents of $\mathrm{BM}$ rice straw significantly $(\mathrm{p}<0.01)$ increased by $50.3 \%, 30.6 \%$ and $16.9 \%$ respectively, while cellulose, ADFom and OM contents significantly $(\mathrm{p}<0.01)$ decreased by $33.1 \%, 29.8 \%$ and $4.5 \%$ respectively. No significant differences $(\mathrm{p}>0.05)$ were detected in ADL and NDFom contents for both strains (Table 1).

\section{SEM and TEM observation}

Rice stems are composed of epidermis, sclerenchyma tissue, parenchyma tissue and vascular bundles. BM and WT stems integrally included all the above tissues (Figure $3 \mathrm{~A}$ and $3 \mathrm{~B}$ ). However, BM had fewer sclerenchyma cells than WT, which are under the epidermal layer (Figure 3A). The alteration in BM sclerenchyma cell walls were identified by TEM observation. Figures 3C and 3D show
Table 1. Chemical composition of brittle mutant (BM) and its wild type (WT) rice straw (All values $\mathrm{g} / \mathrm{kg} \mathrm{DM}$, except for DM content $\mathrm{g} / \mathrm{kg}$ fresh straw)

\begin{tabular}{lccl}
\hline & WT & BM & SEM \\
\hline Dry matter & $270.8^{\mathrm{a}}$ & $224.6^{\mathrm{b}}$ & 1.49 \\
Organic matter & $823.4^{\mathrm{a}}$ & $785.9^{\mathrm{b}}$ & 0.37 \\
Crude protein & $49.2^{\mathrm{b}}$ & $57.5^{\mathrm{a}}$ & 0.07 \\
NDFom & $811.8^{\mathrm{a}}$ & 795.5 & 2.17 \\
ADFom & $492.8^{\mathrm{a}}$ & $345.9^{\mathrm{b}}$ & 0.57 \\
Cellulose & $421.7^{\mathrm{a}}$ & $282.0^{\mathrm{b}}$ & 2.74 \\
Hemicellulose & $285.0^{\mathrm{b}}$ & $428.3^{\mathrm{a}}$ & 0.54 \\
ADL & 61.0 & 63.9 & 0.66 \\
AIA & $126.9^{\mathrm{b}}$ & $165.7^{\mathrm{a}}$ & 1.02 \\
\hline
\end{tabular}

NDFom $=$ Neutral detergent fiber on ash-free basis; ADFom $=$ Acid detergent fiber on ash-free basis; $\mathrm{ADL}=$ Acid detergent lignin; $\mathrm{AIA}=$ Acid insoluble ash; DM = Dry matter. In the same row, values with different letters are significantly different $(\mathrm{p}<0.05)$.

that the BM had thinner sclerenchyma cell walls than WT.

\section{In situ digestibility}

In situ digestibility of BM rice straw was greatly influenced by gene mutation. Table 2 shows that there were no differences in in situ DM disappearance at $24 \mathrm{~h}$ of incubation between both strains. However, DM and NDFom disappearance of $\mathrm{BM}$ rice straw at $48 \mathrm{~h}$ of incubation was significantly greater than WT $(40.7 \%$ vs $35.5 \%$ for DM, $39.7 \%$ vs $33.6 \%$ for NDFom, $\mathrm{p}<0.05)$. For cell wall components, in situ digestibility of cellulose and hemicellulose for BM rice straw was higher than that of WT

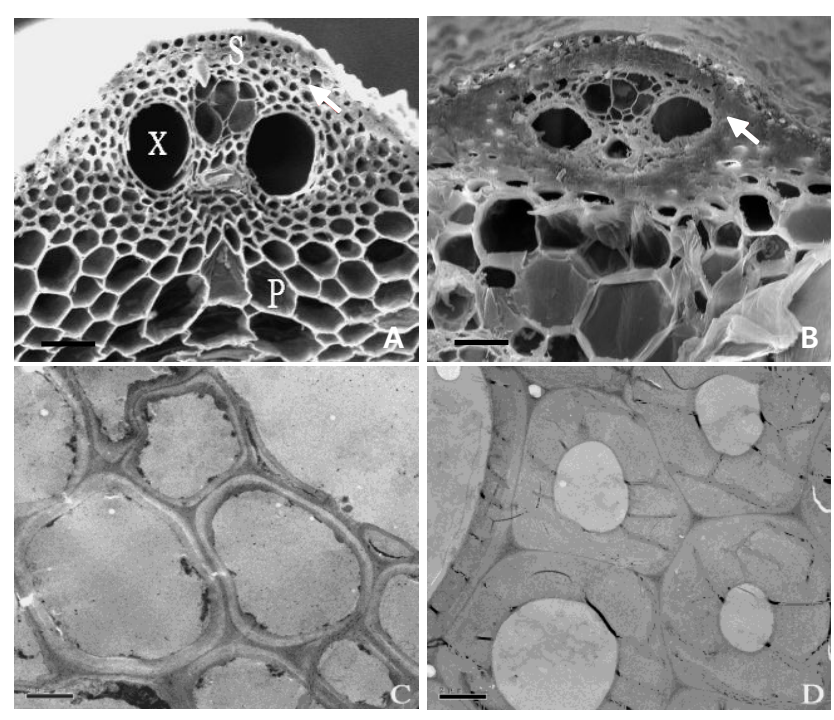

Figure 3. Transverse section and sclerenchyma cells of brittle mutant and its wild type stem. A, transverse section of brittle mutant stem $(\mathrm{S}=$ sclerenchyma; $\mathrm{X}=$ xylem; $\mathrm{P}=$ parenchyma, $\mathrm{SEM} \times 800)$; $\mathrm{B}$, transverse section of wild type stem $(\mathrm{SEM} \times 800)$; C, sclerenchyma cell of brittle mutant stem $(\mathrm{TEM} \times 5,800)$; D, sclerenchyma cell of wild type stem $(\mathrm{TEM} \times 5,800)$. 
Table 2. In situ DM and NDFom disappearance, digestion constants and in situ digestibility of cell wall components for brittle mutant (BM) and its wild type (WT) rice straw

\begin{tabular}{|c|c|c|c|}
\hline Item & WT & $\mathrm{BM}$ & SEM \\
\hline \multicolumn{4}{|l|}{ In situ $\mathrm{DM}$ disappearance } \\
\hline \multicolumn{4}{|l|}{ Disappearance $(\%)$} \\
\hline $24 \mathrm{~h}$ & 29.1 & 29.3 & 1.41 \\
\hline $48 \mathrm{~h}$ & $35.5^{\mathrm{b}}$ & $40.7^{\mathrm{a}}$ & 1.41 \\
\hline \multicolumn{4}{|l|}{ Digestion constants ${ }^{\mathrm{e}}$} \\
\hline Potentially digestible fraction (\%) & $40.7^{\mathrm{b}}$ & $52.9^{\mathrm{a}}$ & 2.12 \\
\hline Readily digested fraction $(\%)$ & $3.6^{\mathrm{b}}$ & $8.3^{\mathrm{a}}$ & 1.06 \\
\hline Slowly digested fraction $(\%)$ & $37.0^{\mathrm{b}}$ & $44.6^{\mathrm{a}}$ & 2.18 \\
\hline Rate of digestion $(\% / \mathrm{h})^{\mathrm{f}}$ & $4.0^{\mathrm{a}}$ & $2.8^{\mathrm{b}}$ & 0.47 \\
\hline Effective digestibility (\%) & $26.7^{\mathrm{b}}$ & $31.4^{\mathrm{a}}$ & 1.09 \\
\hline \multicolumn{4}{|l|}{ In situ NDFom disappearance } \\
\hline \multicolumn{4}{|l|}{ Disappearance (\%) } \\
\hline $24 \mathrm{~h}$ & $25.7^{\mathrm{b}}$ & $28.1^{\mathrm{a}}$ & 2.10 \\
\hline $48 \mathrm{~h}$ & $33.6^{\mathrm{b}}$ & $39.7^{\mathrm{a}}$ & 2.45 \\
\hline \multicolumn{4}{|l|}{ Digestion constants ${ }^{\mathrm{e}}$} \\
\hline Potentially digestible fraction (\%) & $37.3^{\mathrm{b}}$ & $53.5^{\mathrm{a}}$ & 2.65 \\
\hline Rate of digestion $(\% / \mathrm{h})^{\mathrm{f}}$ & $4.5^{\mathrm{a}}$ & $3.0^{\mathrm{b}}$ & 0.44 \\
\hline Lag time $(\mathrm{h})$ & $0.8^{\mathrm{a}}$ & $0.3^{\mathrm{b}}$ & 0.15 \\
\hline Effective digestibility (\%) & $24.3^{\mathrm{b}}$ & $29.1^{\mathrm{a}}$ & 1.12 \\
\hline \multicolumn{4}{|c|}{ In situ digestibility of cell wall components } \\
\hline \multicolumn{4}{|l|}{ Cellulose digestibility (\%) } \\
\hline $24 \mathrm{~h}$ & $32.7^{\mathrm{b}}$ & $38.5^{\mathrm{a}}$ & 3.36 \\
\hline $48 \mathrm{~h}$ & $44.1^{\mathrm{b}}$ & $54.2^{\mathrm{a}}$ & 2.75 \\
\hline $72 \mathrm{~h}$ & $48.8^{\mathrm{b}}$ & $54.9^{\mathrm{a}}$ & 1.59 \\
\hline \multicolumn{4}{|l|}{ Hemicellulose digestibility (\%) } \\
\hline $24 \mathrm{~h}$ & $35.4^{\mathrm{b}}$ & $45.5^{\mathrm{a}}$ & 2.48 \\
\hline $48 \mathrm{~h}$ & 46.2 & 50.9 & 2.41 \\
\hline $72 \mathrm{~h}$ & $48.8^{\mathrm{b}}$ & $61.7^{\mathrm{a}}$ & 3.1 \\
\hline
\end{tabular}

DM = Dry matter; NDFom = Neutral detergent fiber on ash-free basis. In the same row, values with different letters are significantly different $(\mathrm{p}<0.05)$.

${ }^{\mathrm{e}}$ In situ digestion constants were calculated using the nonlinear model $\mathrm{P}=$ $\mathrm{a}+\mathrm{b}\left(1-\mathrm{e}^{-\mathrm{ct}}\right)$ of Ørskov and McDonald (1979).

${ }^{\mathrm{f}}$ Rate of digestion of slowly digested fraction.

during incubation time.

As for digestion constants in Table 2, the effective digestibility of DM and NDFom for BM rice straw was significantly higher than WT $(31.4 \%$ vs $26.7 \%$ for DM, $29.1 \%$ vs $24.3 \%$ for NDFom, $\mathrm{p}<0.05$ ). Meanwhile, BM had a higher potentially digestible fraction of DM and NDFom and lower lag time than WT. The rate of digestion of the slowly digested fraction of DM and NDFom of BM rice straw was decreased $(\mathrm{p}<0.05)$ compared to WT.

\section{DISCUSSION}

The mechanical strength of cereal straw is an important factor that influences processing such as chopping, kneading and grinding, which are directly related to the utilization profile of cereal straw. A number of studies have revealed the effects of reducing forage particle size on chewing activities and feeding behavior (Bal et al., 2000; Beauchemin and Yang, 2005). Welch (1982) demonstrated that forage particle size was an important factor in determining the passage of particles from the rumen. Kononoff et al. (2003) revealed that reducing particle size would increase dry matter intake and improve rumen fermentation. In this study, BM rice straw exhibited a fragile culm and leaf (Figure 1). Although the brittle trait could induce lodging during plant growth, it was obvious that this trait was favorable for processing adequate particle size in chewing or feeding.

The chemical composition is an important indicator in the estimation of the nutritional value of feeds and forages. High NDF content could limit rumen intake, and ADF content is negatively related with forage digestibility. In this study BM rice straw contained lower ADFom content and similar NDFom content compared with WT (Table 1). Furthermore, in the grasses, hemicellulose was more digestible than cellulose for ruminants (Keys et al., 1969). This is consistent with our results that in situ digestibility of hemicellulose was higher than cellulose for both strains (Table 2). Agbagla-Dohnani et al. (2001) revealed that rice straw DM degradation was positively related to the hemicellulose content, whereas increasing cellulose and lignin content tended to decrease the DM degradation. BM showed higher hemicellulose content and lower cellulose content than WT, but no difference in lignin content (Table 1). These chemical characteristics imply that BM rice straw could have improved nutritive value.

The plant morphological tissues, including epidermis, sclerenchyma, parenchyma and vascular, had a different response to degradation by ruminal microorganism. SEM and TEM observation showed that sclerenchyma of rice straw stem still remained intact at $72 \mathrm{~h}$ incubation, while the parenchyma was digested completely after $48 \mathrm{~h}$ of incubation (Wang et al., 2008). For rice straw stem epidermis, most of the cuticle wax layer was intact after 12 $\mathrm{h}$ of rumen incubation, while cracking of the cuticle wax and silica layer could be observed after $48 \mathrm{~h}$ of incubation (Wang et al., 2007). In this study BM showed fewer sclerenchyma cells and a thinner sclerenchyma cell wall than its wild type (Figure 3). The nutritional value of cereal straws is also related to their botanic characteristics (AbouEl-Enin et al., 1999; Agbagla-Dohnani et al., 2001). Vadiveloo et al. (2000) revealed that the digestibility of rice morphological fractions were different, and followed as: Stem>leaf sheath>leaf blade. BM had larger leaf sheath proportion than that of WT (Figure 2). These morphological and histological characteristics provide an important explanation of why $\mathrm{BM}$ rice straw had an improved 
degradability.

Actually, in most rice-producing countries the improvement of the feeding value of rice straw is out not considered in their modern breeding programs. Brittle culml (bcl), which was due to defect in COBRA gene, was the only brittle mutant whose nutritive value has been evaluated (Wang et al., 2006). They showed that there was no difference in organic matter digestibility (OMD) between $b c l$ and its wild types. However, the DM and NDFom digestibility of $\mathrm{BM}$ rice straw were significantly $(\mathrm{p}<0.01)$ higher than that of its wild type (Table 2). This inconsistency between $\mathrm{BM}$ and $\mathrm{Bcl}$ digestibility could be ascribed to many differences between both, including the mutative gene, plant varieties, and cell wall matrix. Especially, the difference in the cell wall matrix could be the most critical difference, as this determines cellulolytic bacterial adhesion. Further studies on the effects of cellulose synthase gene mutations on the adhesion of rumen cellulolytic bacteria and other rumen microorganism populations may uncover the essential mechanism of improved digestibility of BM rice straw.

\section{ACKNOWLEDGEMENTS}

This work was supported by the national key Technology R\&D Program of china (2006BAD04A03-07) and Natural Science of china (30871800).

\section{REFERENCES}

Abou-El-Enin, O. H., J. G. Fadel and D. J. Mackill. 1999. Differences in chemical composition and fibre digestion of rice straw with, and without, anhydrous ammonia from 53 rice varieties. Anim. Feed Sci. Technol. 79:129-136.

Agbagla-Dohnani, A., P. Noziere, G. Clement and M. Doreau. 2001. In sacco degradability, chemical and morphological composition of 15 varieties of European rice straw. Anim. Feed Sci. Technol. 94:15-27.

AOAC. 1999. Official methods of analysis. 16th ed. Association of Official Analytical Chemists, Wahington, DC, USA.

Bal, M. A., R. D. Shaver, A. G. Jirovec, K. J. Shinners and J. G. Coors. 2000. Crop processing and chop length of corn silage: Effects on intake, digestion, and milk production by dairy cows. J. Dairy Sci. 83:1264-1273.

Beauchemin, K. A. and W. Z. Yang. 2005. Effects of physically effective fiber on intake, chewing activity, and ruminal acidosis for dairy cows fed diets based on corn silage. J. Dairy Sci. 88:2117-2129.

Guo, T. S., M. D. Sánchez and P. Y. Guo. 2002. Animal production based on crop residues-chinese experiences. In: Introduction (Ed. T. S. Guo and Z. H. Yang). FAO, Rome, Italy. pp. 6-8.

Jung, H. G. and M. S. Allen. 1995. Characteristics of plant cell walls affecting intake and digestibility of forages by ruminants. J. Anim. Sci. 73:2774-2790.

Karunanandaa, K., G. A. Varga, D. E. Akin, L. L. Rigsby and D. J.
Royse. 1995. Botanical fractions of rice straw colonized by white-rot fungi: Changes in chemical composition and structure. Anim. Feed Sci. Technol. 55:179-199.

Keys, J. E., P. J. Van Soest and E. P. Young. 1969. Comparative study of the digestibility of forage cellulose and hemicellulose in ruminants and nonruminants. J. Anim. Sci. 29:11-15.

Kononoff, P. J., A. J. Heinrichs and H. A. Lehman. 2003. The effect of corn silage particle size on eating behavior, chewing activities, and rumen fermentation in lactating dairy cows. J. Dairy Sci. 86:3343-3353.

Liu, J. X. and E. R. Ørskov. 2000. Cellulase treatment of untreated and steam pre-treated rice straw-effect on in vitro fermentation characteristics. Anim. Feed Sci. Technol. 88:189-200.

Liu, J. X., A. Susenbeth and K. H. Südekum. 2002. In vitro gas production measurements to evaluate interactions between untreated and chemically treated rice straws, grass hay, and mulberry leaves. J. Anim. Sci. 80:517-524.

McDonald, I. M. 1981. A revised model for the estimation of protein degradability in rumen. J. Agric. Sci. (Camb.) 96:251252.

Persson, S., H. Wei, J. Milne, G. P. Page and C. R. Somerville. 2005. Identification of genes required for cellulose synthesis by regression analysis of public microarray data sets. Proc. Natl. Acad. Sci. USA 102:8633-8638.

Ørskov, E. R. and L. McDonald. 1979. The estimation of protein degradability in the rumen from incubation measurements weighted according to rate of passage. J. Agric. Sci. (Camb.) 92:499-503.

Rahal, A., A. Singh and M. Singh. 1997. Effect of urea treatment and diet composition on, and prediction of nutritive value of rice straw of different cultivars. Anim. Feed Sci. Technol. 68: 165-182.

Selim, A. S. M., J. Pan, T. Takano, T. Suzuki, S. Koike, Y. Kobayashi and K. Tanaka. 2004. Effect of ammonia treatment on physical strength of rice straw, distribution of straw particles and particle-associated bacteria in sheep rumen. Anim. Feed Sci. Technol. 115:117-128.

Singh, M. and H. P. Singh. 1995. Genetic variation in chemical composition and digestibility of nutrients in rice straw. Int. Rice Res. Notes 20:4.

Sohane, R. K. and M. Singh. 2000. Genetic variability and prediction of nutritive value of rice straw of different cultivars. Indian J. Anim. Nutr. 17:271-278.

Vadiveloo, J. 2000. Nutritional properties of the leaf and stem of rice straw. Anim. Feed Sci. Technol. 83:57-65.

Vadiveloo, J. and J. G. Fadel. 2009. The response of rice straw varieties to urea treatment. Anim. Feed Sci. Technol. 151:291298.

Van Soest, P. J., J. B. Robertson and B. A. Lewis. 1991. Methods for dietary fiber, neutral detergent fiber, and nonstarch polysaccharides in relation to animal nutrition. J. Dairy Sci. 74:3583-3597.

Wang, H. F., Y. M. Wu, J. X. Liu and Q. Qian. 2006. Morphological fractions, chemical compositions and in vitro gas production of rice straw from wild and brittle culm1 variety harvested at different growth stages. Anim. Feed Sci. Technol. 129:159-171.

Wang, J. K., X. L. Chen, J. X. Liu, Y. M. Wu and J. A. Ye. 2008. Histological changes of tissues and cell wall of rice straw 
influenced by chemical pretreatments. Asian-Aust. J. Anim. Sci. 21:824-830.

Wang, J. K., J. X. Liu, J. Y. Li, Y. M. Wu and J. A. Ye. 2007. Histological and rumen degradation changes of rice straw stem epidermis as influenced by chemical pretreatment. Anim. Feed Sci. Technol. 136:51-62.

Weimer, P. J., D. R. Mertens, E. Ponnampalam, B. F. Severin and B. E. Dale. 2003. Fibex-treated rice straw as a feed ingredient for lactating dairy cows. Anim. Feed Sci. Technol. 103:41-50.
Welch, J. G. 1982. Rumination, particle size and passage from the rumen. J. Anim. Sci. 54:885-894.

Wilman, D., G. R. Foulkes and D. I. Grivens. 1996. A comparison of four methods of estimating the rate and extent of cell wall degradation in grass silages. Anim. Feed Sci. Technol. 63:99109

Yan, C., S. Yan, X. Zeng, Z. Zhang and M. Gu. 2007. Fine mapping and isolation of $b c 7(\mathrm{t})$, allelic to OsCesA4. J. Genet. Genomics 34:1019-1027. 